\title{
ASPEK-ASPEK SYARIAH DALAM ASURANSI SYARIAH
}

\author{
Muhammad Tho'in ${ }^{1}$ dan Anik ${ }^{2}$ \\ STIE-AAS Surakarta \\ ${ }^{I}$ Email: thoinsyakira@yahoo.com \\ ${ }^{2}$ Email: karjunianik@yahoo.co.id
}

\begin{abstract}
This study is to analyze aspects of sharia in Islamic insurance. Theories related to this study include about Ijara, Ijara financing, DSN-MUI fatwa, Ijara financing application. This study is qualitative descriptive. Data collection methods used in this research is the study of literature. The results showed that Takaful insurance aspect is clear then can be applied in the system of Islamic insurance. Takaful is a system where the participants / members / participants donate or donate part or all of the contribution that will be used to pay claims, in case of disaster experienced by most participants/members/participants. The role of the company here is limited to the operational management of insurance companies and investment funds / contributions received or transferred to the company.
\end{abstract}

Keywords: Aspects of Sharia in the Takaful and Insurance Non-Sharia

\section{Pendahuluan}

Seiring dengan perkembangan jaman, kini telah berkembang dengan pesat lembaga keuangan syariah, yang diantaranya adalah Asuransi Syariah. Asuransi pada awalnya adalah suatu kelompok yang bertujuan untuk membentuk arisan atau meringankan beban keuangan individu dan menghindari kesulitan pembiayaan. Secara umum konsep asuransi merupakan persiapan yang dibuat oleh sekelompok orang yang masing-masing menghadapi kerugian kecil sebagai suatu yang tidak dapat diduga. Apabila kerugian itu menimpa salah satu dari mereka yang menjadi anggota kumpulan itu, maka kerugian itu akan ditanggung bersama oleh mereka. ${ }^{1}$

Kitab undang-undang (UU) Hukum Dagang pasal 246 memberikan pengertian asuransi sebagai berikut: "asuransi atau pertanggungan adalah suatu perjanjian, dengan mana seorang menanggung mengikat diri kepada seorang tertanggung, dengan menerima premi, untuk memberikan penggantian kepadanya karena suatu kerugian, kerusakan atau kehilangan keuntungan yang diharapkan, yang mungkin

\footnotetext{
${ }^{1}$ Heri Sudarsono, Bank Dan Lembaga Keuangan Syariah Deskripsi Dan Ilustrasi, Cet 1, (Yogyakarta: Ekonisia 2003), hal. 118
} 
akan dideritanya karena suatu peristiwa yang tak tertentu."

Menurut pasal 1 undang-undang no. 2 tahun 1992 tentang usaha perasuransian, asuransi atau pertanggungan adalah perjanjian antara dua pihak atau lebih, dengan mana pihak penanggung mengikat diri kepada tertanggung, dengan menerima premi asuransi, untuk memberikan penggantian kepada tertanggung karena kerugian, kerusakan atau kehilangan keuntungan yang diharapkan, atau tanggung jawab hukum pada pihak ketiga yang mungkin ada diderita tertanggung, yang timbul dari suatu peristiwa yang tidak pasti, atau untuk memberikan suatu pembayaran yang didasarkan atas meninggal atau hidupnya seseorang yang dipertanggungkan. ${ }^{3}$

Adanya lembaga penjamin yang mampu menangani permasalahan tersebut sangatlah diharapkan. Hadirnya Asuransi merupakan jalan terang terbukanya harapan ini. Sebenarnya konsep asuransi islam sudah diterapkan pada Zaman Rasulullah yang disebut dengan Aqilah. Menurut Thomas Patrick dalam bukunya Dictionary of Islam, hal ini sudah menjadi kebiasaan suku Arab sejak zaman dulu, jika ada salah satu anggota suku yang terbunuh oleh anggota dari suku lain, pewaris korban akan dibayar sejumlah uang darah (diyat) sebagai kompensasi oleh saudara terdekat dari pembunuh. Saudara terdekat pembunuh

\footnotetext{
${ }^{2}$ M. Solahudin, Lembaga Ekonomi dan Keuangan Islam, (Surakarta : Muhammadiyah University Press, 2006), hal. 127.

${ }^{3}$ Heri sudarsono, Bank dan Lembaga Keuangan Syariah Deskripsi dan Ilustrasi, cet 2, (Yogyakarta: Ekonisia, 2004), hal. 112
}

Jurnal IImiah Ekonomi Islam - Vol. 01, No. 01, Maret 2015 tersebut disebut Aqilah, harus membayar uang darah atas nama pembunuh. ${ }^{4}$

\section{Asuransi dan Asuransi Syariah}

Kata asuransi berasal dari bahasa Belanda, assurantie, yang dalam hukum Belanda disebut Verzekering yang artinya pertanggungan. Dari peristilahan assurantie kemudian timbul istilah assuradeur bagi penanggung dan greassureerde bagi tertanggung. ${ }^{5}$ Dalam bahasa Arab Asuransi disebut at-ta'min, penanggung disebut mu'ammin, sedangkan tertanggung disebut mu'amman lahu atau musta'min. Menta'min-kan sesuatu, artinya adalah seseorang membayar/menyerahkan uang cicilan agar ia atau ahli warisnya mendapatkan sejumlah uang sebagaimana yang telah disepakati, atau untuk mendapatkan ganti terhadap hartanya yang hilang. ${ }^{6}$

Istilah lain yang sering digunakan untuk asuransi islam adalah takaful yang berasal dari kata kafala yang berarti menanggung, menjamin; yakfulu, kuflan, seperti ${ }^{7}$ QS. Ali Imran: 44:

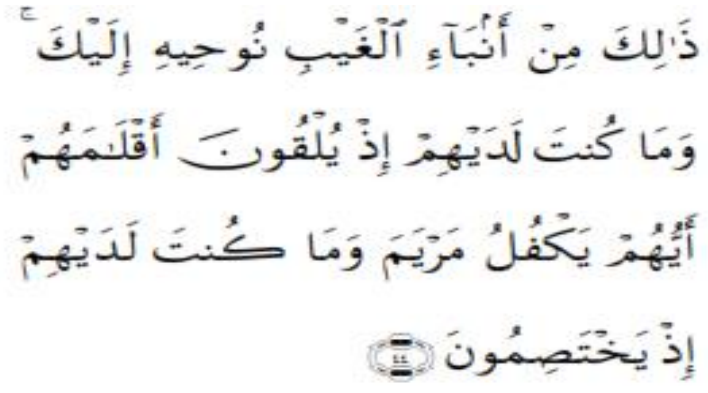

${ }^{4}$ Muhammad Syakir Sula, Asuransi Syariah (life and general), (jakarta: Gema Insani Press,2004), hal. 30-31

${ }^{5}$ Ibid, hal. 26

${ }^{6}$ Ibid, hal. 28

${ }^{7}$ Nurul Huda dan Mohamad Heykal, Lembaga Keuangan Islam: Tinjauan Teoritis Dan Praktis, (Jakarta: Prenada Media Group, 2010), Hal. 153-154 
44. yang demikian itu adalah sebagian dari berita-berita ghaib yang Kami wahyukan kepada kamu (ya Muhammad); Padahal kamu tidak hadir beserta mereka, ketika mereka melemparkan anak-anak panah mereka (untuk mengundi) siapa di antara mereka yang akan memelihara Maryam. dan kamu tidak hadir di sisi mereka ketika mereka bersengketa.

Selain itu, dalam QS. Taha: 40:

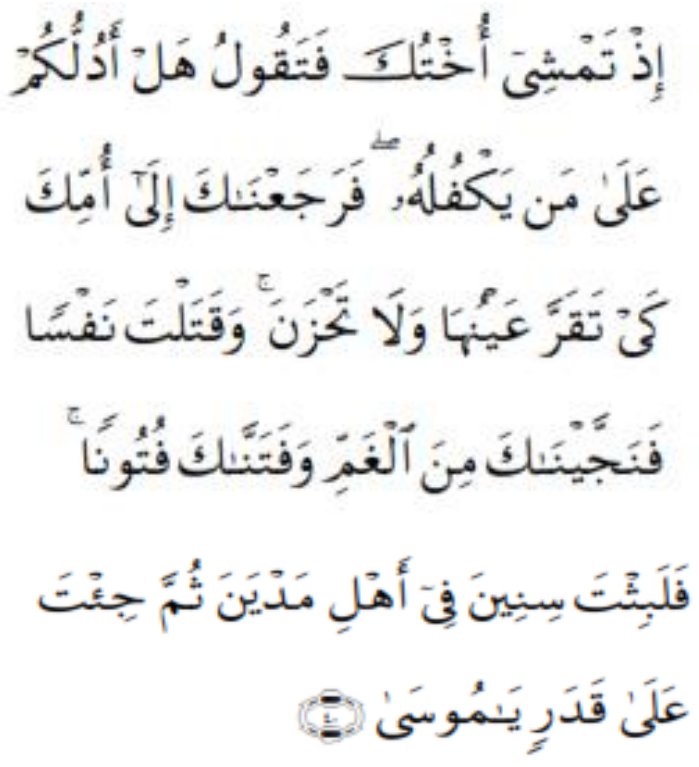

40. (yaitu) ketika saudaramu yang perempuan berjalan, lalu ia berkata kepada (keluarga Fir'aun): "Bolehkah saya menunjukkan kepadamu orang yang akan memeliharanya?" Maka Kami mengembalikanmu kepada ibumu, agar senang hatinya dan tidak berduka cita. dan kamu pernah membunuh seorang manusia[917], lalu Kami selamatkan kamu dari kesusahan dan Kami telah mencobamu dengan beberapa cobaan; Maka kamu tinggal beberapa tahun diantara penduduk Madyan[918], kemudian kamu datang menurut waktu yang ditetapkan[919] Hai Musa,

[917] Yang dibunuh Musa a.s. ini ialah seorang bangsa Qibthi yang sedang berkelahi dengan seorang Bani Israil, sebagaimana yang dikisahkan dalam surat Al Qashash ayat 15.

[918] Nabi Musa a.s. datang ke negeri Mad-yan untuk melarikan diri, di sana Dia dikawinkan oleh Nabi Syu'aib a.s. dengan salah seorang puterinya dan menetap beberapa tahun lamanya.

[919] Maksudnya: Nabi Musa a.s. datang ke lembah Thuwa untuk menerima wahyu dan kerasulan.

Dan firman Allah dalam QS. Al-Qashash: 12:

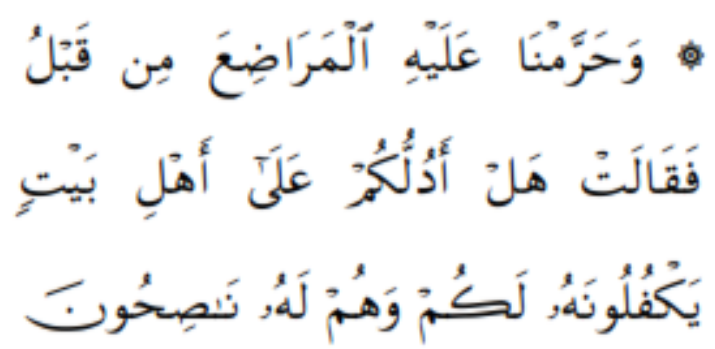

12. dan Kami cegah Musa dari menyusu kepada perempuan-perempuan yang mau menyusui(nya) sebelum itu; Maka berkatalah saudara Musa: "Maukah kamu aku tunjukkan kepadamu ahlul bait yang akan memeliharanya untukmu dan mereka dapat Berlaku baik kepadanya?".

Adapun kata takaful saling menanggung, penjamin seperti terdapat dalam QS. AnNahl: 21: 


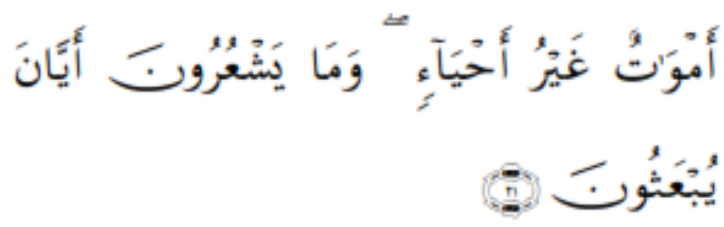

21. (Berhala-berhala itu) benda mati tidak hidup, dan berhala-berhala tidak mengetahui bilakah penyembahpenyembahnya akan dibangkitkan.

Dewan Syariah Nasional Majelis Ulama Indonesia Thun 2001 dalam fatwa DSN No. 21/DSN-MUI/X/2001 bagian Pertama mengenai Ketentuan Umum angka 1, disebutkan bahwa Asuransi Syariah (Ta'min, Takaful, Tadhamun) adalah usaha saling melindungi dan tolong menolong diantara sejumlah pihak/orang melalui investasi dalam bentuk asset atau tabarru' yang memberikan pola pengembalian untuk mengahadapi resiko tertentu melalui akad (perikatan) yang sesuai dengan syariah. ${ }^{8}$

Oleh sebab itu, premi pada Asuransi Syariah adalah sejumlah dana yang dibayarkan oleh peserta yang terdiri atas Dana Tabungan dan Tabarru. Dana Tabungan adalah dana titipan dari peserta Asuransi Syariah (life insurance) dan akan mendapat alokasi bagi hasil (almudharabah) dari pendapatan investasi bersih yang diperoleh setiap tahun. Dana tabungan beserta alokasi bagi hasil akan dikembalikan kepada peserta apabila yang bersangkutan mengajukan klaim, baik berupa klaim manfaat asuransi. Sedangkan, Tabarru' adalah derma tau dana kebajikan yang diberikan dan diikhlaskan oleh peserta

\footnotetext{
${ }^{8}$ Fatwa Dewan Syariah Nasional No. 21/DSN-MUI/X/2001 Tentang Pedoman Umum Asuransi Syariah
}

Jurnal IImiah Ekonomi Islam - Vol. 01, No. 01, Maret 2015 asuransi jika sewaktu-waktu akan dipergunakan untuk membayar klaim atau manfaat asuransi ( life maupun general insurance ). ${ }^{9}$ Asuransi syariah adalah suatu pengaturan pengelolaan risiko yang memenuhi ketentuan syariah, tolongmenolong secara mutual yang melibatkan peserta dan operator. Syariah berasal dari ketentuan-ketentuan di dalam Al-Quran (firman Allah yang disampaikan kepada Nabi Muhammad saw) dan As-Sunnah (teladan dari kehidupan Nabi Muhammad saw). ${ }^{10}$

\section{LandasanHukumAsuransiSyariah}

\section{Al-Qur'an}

1. Surah al-Maidah ayat 2

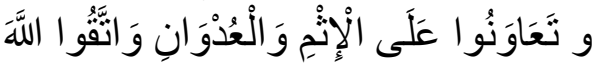

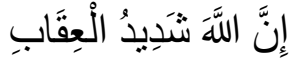

Artinya: “... tolong-menolonglah kamu dalam (mengerjakan) kebaikan dan takwa, dan jangan tolongmenolong dalam berbuat dosa dan pelanggaran. Dan bertakwalah kamu kepada Allah, sesungguhnya Allah amat berat siksanya". (Q.S, al-Maidah $5: 2)$

2. Surah al-Baqarah ayat 185

$$
\begin{aligned}
& \text { يُرِيدُ اللَّهُ بِكُمُ الْيُسنرَ وَلَا يُرِيدُ بِكُمُ الْعُسْرَ } \\
& \text { Artinya: "...AAllah menghendaki } \\
& \text { kemudahan bagimu, dan tidak }
\end{aligned}
$$

${ }^{9}$ Muhammad Syakir Sula, ASURANSI SYARIAH (life and general), (jakarta: Gema Insani Press, 2004), hal. 30

${ }^{10}$ Muhaimin Iqbal, Asuransi umum Syariah Dalam Praktik (upaya menghilangkan Gharar, Maisir, Riba), (Jakarta: Gema Insani Press, 2005), hal. 2 
menghendaki kesukaran bagimu...." Q.S, al-Baqarah 2:185

3. Surah al-Baqarah ayat 261

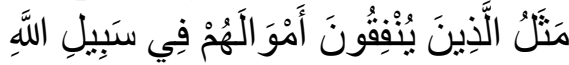

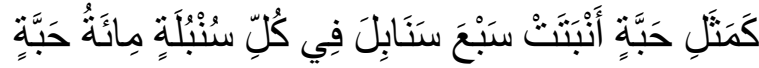

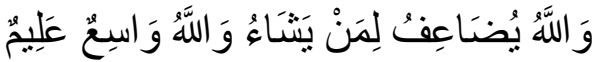

Artinya: " perumpamaan (nafkah yang dikeluarkan oleh) orang-orang yang menafkahkan hartanya dijalan Allah adalah serupa dengan sebutir benih yang menumbuhkan tujuh butir benih, pada tiap-tiap bulir: seratus biji. Allah melipatgandakan (ganjaran) bagi siapa yang dia kehendaki. Dan Allah maha luas (karunia-nya) lagi maha mengetahui. (Q.S, al-Baqarah 2:261)

4. Surah Yusuf ayat 46-49

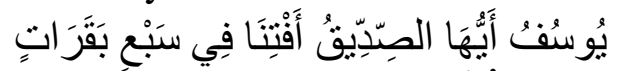

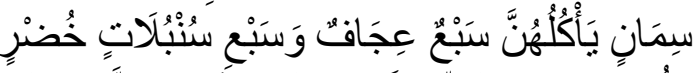

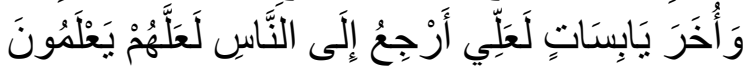

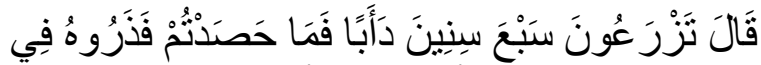

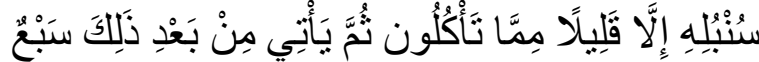

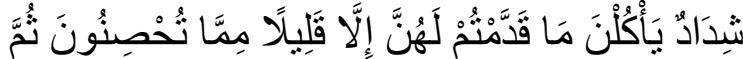

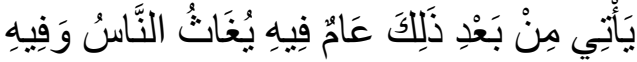

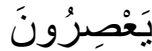

Artinya: "(Setelah pelayan itu berjumpa dengan yusuf dia berseru: "Yusuf, hai orang yang amat yang dipercaya, terangkanlah kepada kami tentang tujuh ekor sapi betina yang kurus-kurus dan dan tujuh bulir (gandum) yang hijau dan (tujuh) lainya yang kering agar aku kembali kepada orang-orang itu, agar mereka mengetahuinya". Yusuf berkata: "Supaya kamu bertanam tujuh tahun (lamanya) sebagaimana biasa; maka apa yang kamu tuaihendaklah kamu biarakan dibulirnya kecuali sedikit untuk kamu makan. Kemudian setelah itu aakan datang tujuh tahun yang amat sulit, yang menghabiskan apa yang kamu simpan untuk menghadapinya (tahun sulit), kecuali sedikit dari (bibit gandum) yang kamu simpan. Kemudian setelah itu akan datangtahun yang padanya manusia diberi hujan (dengan cukup) dan di masa itu mereka memeras anggur). (Q.S, Yusuf 12:46-49)

5. Surah al-Taghaabun ayat 11

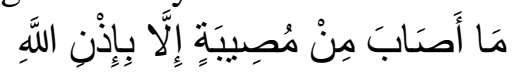

Artinya: tidak ada suatu musibah pun yang menimpa seseorang kecuali dengan izin Allah..." (Q.S, al- Taghaabun $64: 11)$

6. Surah luqman ayat 34

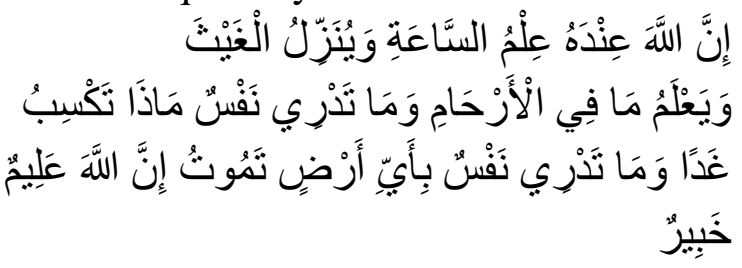

Artinya: "Sesungguhnya Allah, hanya pada sisi-Nya sajalah pengetahuan tentang hari kiamat dan dialah yang menurunkan hujan, dan mengetahui apa yang ada dalam rahim. Dan tidak seorangpun yang mengetahui (dengan pasti) apa yang akan diusahakannya besok; dan tidak seorangpun yang dapat mengetahui dibumi mana ia akan mati. Sesungguhnya Allah Maha Mengetahui lagi maha mengenal." (Q.S, Luqman 31:34)

7. Surah Hud ayat 16 


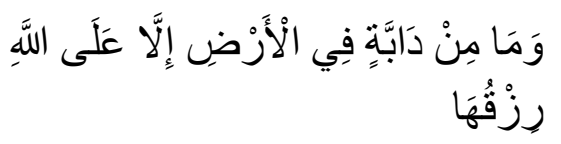

Artinya: "Dan tidak ada suatu binatang melata pun di bumi melainkan Allah-lah yang memberi rezekinya." (Q.S, Hud, 11:16)

8. Surah an-Naml ayat 64

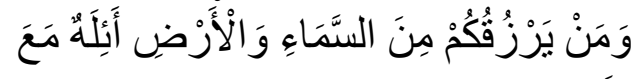

اللَّه

Artinya: “...dan siapa (pula) yang memberikan rezeki kepadamu dari langit dan bumi ? apakah disamping Allah ada tuhan yang lain ?..." (Q.S, An-Naml. 27:64)

9. Surah al-Hijr ayat 20 وَجَعَلْنَا لَكُمْ فِيهَا مَعَايِشَ وَمَنْ لَسنْنُمْ لَلهُ بِرَازِقِينَ

Artinya: " dan kami telah menjadikan untukmu dibumi keperluan-keperluan hidup, dan (kami menciptakan pula) makhluk-makhluk yang kamu sekali-kali bukan memberi rezeki kepadanya.” (Q.S, Al-Hijr, $15: 20)$

Untuk memahami ayat-ayat ini dengan tepat kita harus lebih mendalami persoalannya. Maksud dari ayat-ayat ini tidak berarti bahwa Allah menyediakan makanan dan pakain kepada kita tanpa usaha. Sebenarnya, semua ayat itu membicarakan tentang ekonomi dimasa depan yang penuh kedamaian, yang selalu dibayangkan islam. Dan seperti yang dinyatakan dalam islam bahwa manusia sebagai Khalifah Allah di Bumi, hanya dapat mempertahankan gelarnya yang agung bila ia melaksanakan perintah perintah yang terkandung dalam Al-Qur'an dengan penafsiran yang tepat. Allah menghendaki tiadanya orang yang kehilangan mata pencaharianya yang layak, dan ia harus kebal terhadap setiap gangguan apapun. Oleh karena itu adalah kewajiban tertinggi dari suatu negara untuk menjamin hal ini. Dan asuransi membantu tercapainya tujuan ini. ${ }^{11}$

Mengenai hal ini, boleh dikemukakan bahwa terdapat sekelompok orang yang tidak dapat membedakan antar asuransi dengan perjudian, mereka menyamakan asuransi dengan spekulasi. Padahal dengan asuransi orang yang menjadi tanggungan dari seorang yang meninggal dunia terlebih dahulu dapat menerima keuntungan lumayan nuntuk sejumlah untuk sejumlah kecil uang yang telah dibayar almarhum sebagai premi. Tampaknya hal ini seperti sejenis perjudian. Tetapi perbedaanya antara asuransi dengan perjudian adalah fundamental, karena dasar asuransi adalah kerja sama yang diakui dalam islam.

Pada kenyataanya ciri khas asuransi adalah pembayaran dari semua peserta untuk membantu tiap peserta lainnya bila dibutuhkan. Prinsip saling menguntungkan ini tidak terbatas dalam kadar paling ringan bagi perusahaan bersama tapi berlaku juga untuk semua organisasi asuransi mana pun walau bgai mana pun struktur hukumnya. ${ }^{12}$

\section{Hadist}

\footnotetext{
${ }^{11}$ AM. Hasan Ali, Asuransi Dalam Perspektif hukum Islam, (Jakarta; Prenada Media, 2004), hal. 105-110

${ }^{12}$ Muhamad Abdul Manan, Teori dan Praktek Ekonomi Islam, (Yogyakarta: Dana Bhakti Wakaf) hal. 301-302
} 


$$
\begin{aligned}
& \text { عن أ بي هر يرة (ر ض) عن النبي }
\end{aligned}
$$

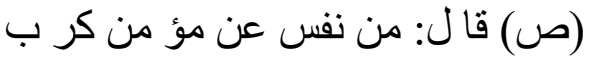

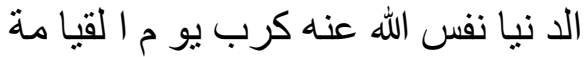

$$
\begin{aligned}
& \text { ومن يسر على معسر يسر الله عليه فى ملى مله } \\
& \text { الدنيا وا لأخرة (رو اه مسلم) لينر) }
\end{aligned}
$$

Artinya: "diriwayatkan oleh Abu Hurairah ra, Nabi Muhammad bersabda: Barangsiapa yang menghilangkan kesulitan duniawinya seorang mukmin, maka Allah SWT. Akan menghilangkan kesulitangnya pada hari kiamat, barang siapa yang mempermudah kesulitan seseorang, maka Allah SWT. Akan mempermudah urusan dunia dan akhirat. (HR. Muslim). ${ }^{13}$

\section{PandanganUlamaTentangAsuransi}

Konsep dan perjanjian asuransi $(a q d u$ at-ta'miin) merupakan jenis akad baru yang belum pernah ada pada masa-masa pertama perkembangan fiqih islam. Perbedaan pendapat bermunculan dari para ulama fiqih masa kini (mu'assirah). Diantara ulama ada yang menghalalkan da nada yang mengharamkan, kemudian ada pula yang mengharamkan asuransi hanya pada sebagian jenisnya.

1. Ulama yang berpendapat asuransi dalam segala aspeknya haram termasuk asuransi jiwa. Pendapat ini didukung oleh kalangan ulama seperti Sayid Sabiq, Abdullah al- Qalqii, Muhammad Yusuf Qordawi dan Muhammad Bakhit alMuth'i. Adapun alasan-alasan mereka mengharamkan asuransi antara lain :

a) Pada dasarnya asuransi itu sama atau serupa dengan judi

b) Asuransi mengandung ketidakpastian

\footnotetext{
${ }^{13}$ AM. Hasan Ali, Asuransi Dalam Perspektif hukum Islam. Hal. 116
}

Jurnal IImiah Ekonomi Islam - Vol. 01, No. 01, Maret 2015 c) Asuransi mengandung riba

d) Asuransi bersifat eksploitas karena premi yang dibayarkan oleh peserta, jika tidak sanggup melanjutkan perjanjian maka premi hangus/ hilang atau dikurangi secara tidak adil ( peserta dizalimi )

e) Premi yang diterima oleh perusahaan diputar atau ditanam pada investasi yang mengandung riba / bunga

f) Asuransi termasuk akad sharfi, artinya jual beli atau tukar menukar uang dengan tidak tunai.

g) Asuransi menjadikan hidup atau mati seseorang sebagai objek bisnis, yang berarti mendahului takdir Allah

Pendapat pertama ini mengarah pada praktek asurani konvensional yang mengandung gharar ( ketidakpastian ), maisir ( untung- untungan ) dan riba serta menempatkan posisi peserta sebagai pihak yang terzalimi karena adanya loss premium.

2. Ulama yang berpendapat membolehkan asuransi termasuk asuransi jiwa dalam prakteknya sekarang. Pendapat ini didukung oleh ulama seperti Abdul Wahab Khallaf, Mustafa Ahmad Zarqa, Muhammad Yusuf Musa dan Abdurrahman isa. Alasan mereka memperbolehkannya adalah:

a) Tidak ada nas Al Quran dan Hadis yang melarang asuransi

b) Ada kesepakatan antara kedua belah pihak

c) Mengandung kepentingan umum ( maslahah 'amah ), sebab premi premi yang terkumpul bisa diinvestasikan untuk proyek- proyek 
yang produktif dan untuk pembangunan

d) Asuransi termasuk akad mudharabah , artinya akad kerja sama bagi hasil antara pemegang polis ( pemilik modal ) dengan pihak perusahaan asuransi yang memutar modal atas dasar profit and loss sharin

e) Asuransi termusak koperasi (syirkah ta'awwuniah)

f) Diqiyaskan (analogi) dengan system pension

Pendapatan kedua ini menitikberatkan pada jenis asuransi sosial dan koperasi yang dikelolaoleh pemerintah, bertujuan bukan komersial, melainkan lebih pada kemaslahatan umat seperti taspen, Jasa Raharja, dan lain sebagainya.

3. Ulama yang berpendapat bahwa asuransi bersifat syuhbat beralasan karena tidak dalil-dalil syar'i yang secara jelas mengharamkan atau menghalalkannya. Bila hukum asuransi dimasukkan dalam hal syubhat, maka kita harus berhati-hati menghadapinya. Kita baru diperbolehkan menggunakan asuransi kalau dalam keadaan darurat dan sangat dibutuhkan. Untuk saat ini setelah munculnya asuransi syariah, maka tidak ada lagi istilah syubhat.

Di kalangan organisasi kemasyarakatan islam di Indonesia (Ormas Islam) Nahdhatul Ulama dalam keputusan munas alim ulama NU di Bandar Lampung tahun 1992 memutuskan bahwa asuransi jiwa hukumnya haram kecuali bila memenuhi ketentuan-ketentuan sebagai berikut : a) Asuransi tersebut harus mengandung tabungan (saving)

b) Peserta yang ikut program asurasi harus bernia menabung

c) Pihak asuransi menginvestasikan dana peserta dengan cara-cara yang dibenarkan oleh syariat islam(bebas dari gharar, maisir dan riba )

d) Apabila peserta mengundurkan diri sebelum jatuh tempo, dana yang telah dibayarkan kepada pihak asuransi tidak hangus.

Apabila suatu ketika pihak tertanggung terpaksa tidak dapat membayar uang premi, maka :

a. Uang premi tersebut menjadi utang yang dapat diangsur oleh pihak tertanggung

b. Hubungan antara pihak tertanggung dengan penanggung tidak terputus

c. Uang tabungan milik tertanggung tidak hangus

d. Apabila sebelum jatuh tempo tertanggung meninggal dunia, maka ahli warisnya berhak mengambil sejumlah uang simpanannya. Sedangkan untuk asuransi kerugian, Munas juga mengeluarkan keputusan bahwa hal itu diperbolehkan dengan ketentuan sebagai berikut :

a) Apabila asuransi kerugian tersebut merupakan persyaratan bagi objekobjek yang menjadi agunan bank

b) Apabila asuransi kerugian tersebut tidak dapat dihindari karena terkait oleh ketentuan - ketentuan pemerintah seperti asuransi untuk barang- barang yang diimpor dan eksport.

Sementara untuk asuransi sosial, munas memutuskan memperbolehkan dengan ketentuan sebagai berikut: 
a) Asuransi sosial tidak termasuk akad muawadhah, tetapi akad syirkah ta'awwuniah.

b) Diselenggarakan oleh pemerintah, sehingga kalau ada kerugian ditanggung oleh pemerintah dan jika ada keuntungan dikembalikan untuk kepentingan masyaraka

\section{PerbedaanAsuransiSyariahDenganAsura} nsi Non-Syariah

\begin{tabular}{|c|c|c|c|}
\hline No & Prinsip & $\begin{array}{c}\text { Auransi } \\
\text { Konvensional }\end{array}$ & $\begin{array}{l}\text { Asuransi } \\
\text { Syrai'ah }\end{array}$ \\
\hline 1. & Konsep & $\begin{array}{l}\text { Perjanjian antara } \\
\text { dua pihak atau } \\
\text { lebih, dengan } \\
\text { mana pihak } \\
\text { penanggung } \\
\text { meningkatkan } \\
\text { diri kepada } \\
\text { tertanggung, } \\
\text { dengan } \\
\text { menerima premi } \\
\text { asuransi, untuk } \\
\text { memberrikan } \\
\text { pergantian } \\
\text { kepada } \\
\text { tertanggung. }\end{array}$ & $\begin{array}{l}\text { Sekumpulan } \\
\text { orang yang } \\
\text { saling } \\
\text { membantu, } \\
\text { saling } \\
\text { menjamin } \\
\text { danm bekerja } \\
\text { sama dengan } \\
\text { cara-cara } \\
\text { masing-masing } \\
\text { mengeluarkan } \\
\text { akad tabarru'. }\end{array}$ \\
\hline 2. & $\begin{array}{l}\text { Visi dan } \\
\text { Misi }\end{array}$ & $\begin{array}{l}\text { Secara garis } \\
\text { besar misi utama } \\
\text { dari asuransi } \\
\text { konvensional } \\
\text { adalah misi } \\
\text { ekonomi dan } \\
\text { misi social. }\end{array}$ & $\begin{array}{l}\text { Misi yang } \\
\text { diemban dalam } \\
\text { asuransi } \\
\text { syariah adalah } \\
\text { misi aqidah, } \\
\text { misi ibadah } \\
\text { (ta'awun ), } \\
\text { misi ekonomi } \\
\text { (iqtishod), dan } \\
\text { misi } \\
\text { pemberdayaan } \\
\text { umat (sosial) }{ }^{14} \text {. } \\
\text { Asuransi } \\
\text { takaful } \\
\text { Indonesia } \\
\text { mempunyai } \\
\text { visi sebagai }\end{array}$ \\
\hline
\end{tabular}

${ }^{14}$ Muhammad Syakir Sula, Asuransi Syariah (life ang general) Konsep dan system Operasional, hal : 326

\begin{tabular}{|c|c|c|c|}
\hline & & & $\begin{array}{l}\text { lembaga } \\
\text { keuangan yang } \\
\text { konsisten } \\
\text { menjalankan } \\
\text { transaksi } \\
\text { asuransi secara } \\
\text { islami. } \\
\text { Operasional } \\
\text { perusahaan } \\
\text { dilaksanakan } \\
\text { atas dasar } \\
\text { prinsip- prinsip } \\
\text { syariah yang } \\
\text { bertujuan } \\
\text { memberikan } \\
\text { fasilitas dan } \\
\text { layanan terbaik } \\
\text { bagi umat } \\
\text { islam } \\
\text { khususnya dan } \\
\text { masyarakat } \\
\text { Indonesia } \\
\text { umumnya. }\end{array}$ \\
\hline 3. & $\begin{array}{l}\text { Sumber } \\
\text { Hukum }\end{array}$ & $\begin{array}{l}\text { Bersumber dari } \\
\text { pikiran manusia } \\
\text { dan kebudayaan. } \\
\text { Berdasarkan } \\
\text { hokum positif, } \\
\text { hokum alami, } \\
\text { dan contoh } \\
\text { sebelumnya. }\end{array}$ & $\begin{array}{l}\text { Bersumber dari } \\
\text { hokum Allah } \\
\text { sumber hokum } \\
\text { dalam Syariah } \\
\text { Islamadalah al } \\
-\quad \text { Qur'an, } \\
\text { sunnah, atau } \\
\text { kebiasaan } \\
\text { Rasul, Ijma', } \\
\text { Fatwa Sahabat, } \\
\text { Qiyas, Istihsan, } \\
\text { Urf "tradisi", } \\
\text { dan Maslahah } \\
\text { Mursalah. }\end{array}$ \\
\hline 4. & Maghrib & $\begin{array}{lr}\text { Tidak } & \text { selaras } \\
\text { dengan } & \text { syariah } \\
\text { islam karena } \\
\text { adanya maisir, } \\
\text { gharar, dan Riba; } \\
\text { hal yang di } \\
\text { haramkan dalam } \\
\text { muamalah }\end{array}$ & $\begin{array}{l}\text { Bersih dari } \\
\text { adanya praktek } \\
\text { gharar, maisir, } \\
\text { dan Riba }\end{array}$ \\
\hline 5. & DPS & $\begin{array}{lr}\text { Tidak } & \text { ada, } \\
\text { segingga } & \text { dalam } \\
\text { banyak } & \\
\text { prakteknya } & \end{array}$ & $\begin{array}{l}\text { Ada, yang } \\
\text { berfungsi untuk } \\
\text { mengawasi } \\
\text { pelaksanaan }\end{array}$ \\
\hline
\end{tabular}

${ }^{15}$ Hermawan Kartajaya dan Muhammad Syakir Sula, Syariah marketing (Bandung: Mizan Pustaka, 2006) hal. 201. 


\begin{tabular}{|c|c|c|c|}
\hline & & $\begin{array}{l}\text { bertentangan } \\
\text { dengan kaidah- } \\
\text { kaidah syara' }\end{array}$ & $\begin{array}{l}\text { operasional } \\
\text { perusahaan } \\
\text { agar terbebas } \\
\text { dari praktek- } \\
\text { praktek } \\
\text { muamalah } \\
\text { yang } \\
\text { bertentangan } \\
\text { dengan prinsip- } \\
\text { prinsip syariah }\end{array}$ \\
\hline 6. & Akad & $\begin{array}{l}\text { Akad jual beli } \\
\text { (akad } \\
\text { mu'awadhah, } \\
\text { akad idz'aan, } \\
\text { akad gharar, dan } \\
\text { akad mulzim) }\end{array}$ & $\begin{array}{l}\text { Akad tabarru' } \\
\text { dan akad ijarah } \\
\text { (mudharabah, } \\
\text { wakalah, } \\
\text { wadiah, } \\
\text { syirkah, dan } \\
\text { sebagainya) }\end{array}$ \\
\hline 7. & $\begin{array}{l}\text { Jaminan / } \\
\text { Risk } \\
\text { (Resiko) }\end{array}$ & $\begin{array}{l}\text { Transfer of risk, } \\
\text { dimana terjadi } \\
\text { transfer resiko } \\
\text { dari tertanggung } \\
\text { kepada } \\
\text { penanggung. }\end{array}$ & $\begin{array}{l}\text { Sharing of risk, } \\
\text { dimana terjadi } \\
\text { proses saling } \\
\text { menanggung } \\
\text { antara satu } \\
\text { peserta dengan } \\
\text { peserta lainnya } \\
\text { (ta'awun) }\end{array}$ \\
\hline 8. & $\begin{array}{l}\text { Pengolahan } \\
\text { Dana }\end{array}$ & $\begin{array}{l}\text { Tidak ada } \\
\text { pemisahan dana, } \\
\text { yang berakibat } \\
\text { pada terjadinya } \\
\text { dana hangus } \\
\text { (untuk produk } \\
\text { saving - life) }\end{array}$ & $\begin{array}{l}\text { Pada produk- } \\
\text { produk saving } \\
\text { (life) terjadi } \\
\text { pemisahan } \\
\text { dana, yaitu } \\
\text { dana tabarru' } \\
\text { derma' dan } \\
\text { dana peserta } \\
\text { sehingga tidak } \\
\text { mengenal } \\
\text { istilah dana } \\
\text { hangus. } \\
\text { Sedangkan } \\
\text { untuk untuk } \\
\text { term insurance } \\
\text { semuanya } \\
\text { bersifat } \\
\text { tabarru' }\end{array}$ \\
\hline 9. & Investasi & $\begin{array}{l}\text { Bebas melakukan } \\
\text { investasi ndalam } \\
\text { batas- batas } \\
\text { ketentuan } \\
\text { perundang- } \\
\text { undangan, dan } \\
\text { tidak terbatasi } \\
\text { pada halal dan } \\
\text { haramnya obyek } \\
\text { atau sistem }\end{array}$ & $\begin{array}{l}\text { Dapat } \\
\text { melakukan } \\
\text { investasi sesuai } \\
\text { ketentuan } \\
\text { perundang- } \\
\text { undangan, } \\
\text { sepanjang tidak } \\
\text { bertentangan } \\
\text { dengan prinsip- } \\
\text { prinsip syariah }\end{array}$ \\
\hline
\end{tabular}

\begin{tabular}{|c|c|c|c|}
\hline & & $\begin{array}{ll}\text { investasi } & \text { yang } \\
\text { digunakan } & \end{array}$ & $\begin{array}{l}\text { islam. Bebas } \\
\text { dari riba dan } \\
\text { tempat- tempat } \\
\text { investasi yang } \\
\text { terlarang. }\end{array}$ \\
\hline 10 & $\begin{array}{l}\text { Kepemilika } \\
\text { n Dana }\end{array}$ & $\begin{array}{l}\text { Dana yang } \\
\text { terkumpul dari } \\
\text { premi peserta } \\
\text { seluruhnya } \\
\text { menjadi milik } \\
\text { perusahaan dan } \\
\text { menginvestasika } \\
\text { n kemana saja. }\end{array}$ & $\begin{array}{l}\text { Dana yang } \\
\text { terkumpul dari } \\
\text { peserta dalam } \\
\text { bentuk iuran } \\
\text { atau kontribusi, } \\
\text { merupakan } \\
\text { milik peserta } \\
\text { (shohibul mal), } \\
\text { asuransi } \\
\text { syariah hanya } \\
\text { sebagai } \\
\text { pemegang } \\
\text { amanah } \\
\text { (mudharib) } \\
\text { dalam } \\
\text { mengelola dana } \\
\text { tersebut. }\end{array}$ \\
\hline 11 & $\begin{array}{l}\text { Keuntungan } \\
\text { (proft) }\end{array}$ & $\begin{array}{l}\text { keuntungan yang } \\
\text { diperoleh dari } \\
\text { surplus } \\
\text { underwriting, } \\
\text { komisi } \\
\text { reansuransi, dan } \\
\text { hasil investasi } \\
\text { seluruhnya } \\
\text { adalah } \\
\text { keuntungan } \\
\text { perusahaan. }\end{array}$ & $\begin{array}{l}\text { Profit yang } \\
\text { diperoleh dari } \\
\text { surplus } \\
\text { underwriting, } \\
\text { komisi } \\
\text { reansuransi, } \\
\text { dan hasil } \\
\text { investasi, } \\
\text { bukan } \\
\text { seluruhnya } \\
\text { menjadi milik } \\
\text { perusahaan, } \\
\text { tetapi } \\
\text { dilakukan } \\
\text { bagi hasil } \\
\text { (mudharabah) } \\
\text { dengan } \\
\text { peserta. }{ }^{16}\end{array}$ \\
\hline
\end{tabular}

Prinsip-Prinsip Umum Muamalah Yang Menlandasi Asuransi Syariah

\footnotetext{
${ }^{16}$ Muhammad Syakir Sula, Asuransi Syariah (life ang general) Konsep dan system Operasional, hal :326- 327
} 
Prinsip-prinsip umum yang melandasi Asuransi Syariah adalah sebagai berikut ${ }^{17}$ :

\section{Tauhid (Ketaqwaan)}

Jika kita mencermati ayat-ayat Alquran tentang muamalah, maka akan terlihat dengan jelas bahwa Allah selalu menyeru kepada umat-Nya agar muamalah yang dilakukan membawanya kepada ketaqwaan kepada Allah. Hal ini misalnya dapat dilihat dalam beberapa ayat berikut ini ${ }^{18}$ :

a. 32. Apakah mereka yang membagibagi rahmat Tuhanmu? Kami telah menentukan antara mereka penghidupan mereka dalam kehidupan dunia, dan Kami telah meninggikan sebahagian mereka atas sebagian yang lain beberapa derajat, agar sebagian mereka dapat mempergunakan sebagian yang lain. dan rahmat Tuhanmu lebih baik dari apa yang mereka kumpulkan. (az-zukhruf: 32)

b. 9. Hai orang-orang beriman, janganlah hartamu dan anak-anakmu melalaikan kamu dari mengingat Allah. Barangsiapa yang berbuat demikian Maka mereka Itulah orang-orang yang merugi. (al-munafiquun: 9)

c. 283. jika kamu dalam perjalanan (dan bermu'amalah tidak secara tunai) sedang kamu tidak memperoleh seorang penulis, Maka hendaklah ada barang tanggungan yang dipegang[180] (oleh yang berpiutang). akan tetapi jika sebagian kamu mempercayai sebagian yang lain, Maka hendaklah yang dipercayai itu

\footnotetext{
${ }^{17}$ Ibid, hal. 722-750

${ }^{18}$ Ibid, hal. 723
}

menunaikan amanatnya (hutangnya) dan hendaklah ia bertakwa kepada Allah Tuhannya; dan janganlah kamu (para saksi) Menyembunyikan persaksian. dan Barangsiapa yang menyembunyikannya, Maka Sesungguhnya ia adalah orang yang berdosa hatinya; dan Allah Maha mengetahui apa yang kamu kerjakan. (al-Baqarah: 283)

Dr. Yusuf al-Qaradhawi dalam salah satu kitabnya Daurul Qiyam wal Akhlaq fil Iqtishadil Islami mengatakan bahwa ekonomi islam adalah ekonomi ilahiah, karena titik berangkatnya dari Allah, tujuannya mencari ridha Allah, dan caracaranya tidak bertentangan dengan syariatNya. Kegiatan ekonomi baik produksi, konsumsi, penukaran, maupun distribusi, diikatkan pada prinsip ilahiah dan pada tujuan ilahi. Manusia muslim berproduksi karena memenuhi perintah Allah. ${ }^{19}$

\section{Al-'Adl (Sikap Adil)}

Prinsip kedua dalam muamalah adalah Al-'Adl sikap adil. Cukuplah bagi kita bahwa Al-quran telah menjadikan tujuan semua risalah langit adalah melaksanakan keadilan. ${ }^{20}$ Syaikh al-Qaradhawi mengatakan bahwa sesungguhnya pilar penyanggah kebebasan ekonomi yang berdiri diatas kemuliaan fitrah dan harkat manusia disempurnakan dan ditentukan oleh pilar penyangga yang lain, yaitu "keadilan". Keadilan dalam islam bukanlah prinsip sekunder. Ia adalah

\footnotetext{
${ }^{19}$ Muhammad Syakir Sula, Asuransi Syariah (life ang general) Konsep dan system Operasional, hal :724

${ }^{20}$ Ibid, hal. 727
} 
cikal bakal dan fondasi kokoh yang melandasi semua ajaran dan hukum islam berupa akidah, syariah, dan akhlak (moral).

Ketika Allah memerintahkan tiga hal, maka keadilan merupakan hal pertama yang disebutkan. Dalam firman Allah:"Sesungguhnya Allah menyuruh (kamu) Berlaku adil dan berbuat kebajikan, memberi kepada kaum kerabat, dan Allah melarang dari perbuatan keji, kemungkaran dan permusuhan. Dia memberi pengajaran kepadamu agar kamu dapat mengambil pelajaran." (an-Nahl: 90)

Ketika Allah memerintahkan dua hal, maka keadilan merupakan salah satu yang disebutkan. Firman Allah: “ Sesungguhnya Allah menyuruh kamu menyampaikan amanat kepada yang berhak menerimanya, dan (menyuruh kamu) apabila menetapkan hukum di antara manusia supaya kamu menetapkan dengan adil. Sesungguhnya Allah memberi pengajaran yang sebaikbaiknya kepadamu. Sesungguhnya Allah adalah Maha mendengar lagi Maha melihat." (an-nisaa:58)

Ketika Allah memerintahkan satu hal, maka keadilan merupakan hal yang diperintahkan tersebut. Allah berfirman: “ Katakanlah: "Tuhanku menyuruh menjalankan keadilan" (al-A'raaf: 29)

3. Asz-Dzulm (Kedzaliman)

Pelanggaran terhadap kedzaliman merupakan salah satu prinsip dasar dalam muamalah. Kedzaliman adalah kebalikan dari sikap keadilan. Karena itu, islam sangat ketat dalam memberikan perhatian terhadap pelanggaran kedzaliman,

Jurnal IImiah Ekonomi Islam - Vol. 01, No. 01, Maret 2015 penegakan larangan terhadapnya, kecaman keras terhadap orang-orang yang dzalim, ancaman terhadap mereka dengan siksa yang paling keras di dunia dan akhirat. Berikut beberapa firman Allah tentang perbuatan dzalim, ${ }^{21}$

"Allah tidak memberi petunjuk kepada orangorang yang zalim." ( al-Baqarah:258)

"Sesungguhnya orang-orang yang aniaya itu tidak mendapat keberuntungan.” (al-An'aam:21)

" Maka Itulah rumah-rumah mereka dalam Keadaan runtuh disebabkan kezaliman mereka." (an-Naml: 52)

4. At-Ta'awun (Tolong-Menolong)

Berikut ini dahlil-dahlil dala Al-Quran tentang ta'awun:

"Dan tolong-menolonglah kamu dalam (mengerjakan) kebajikan dan takwa, dan jangan tolong-menolong dalam berbuat dosa dan pelanggaran. dan bertakwalah kamu kepada Allah, Sesungguhnya Allah Amat berat siksaNya. "(al-Maa'idah: 2)

Diriwayatkan dari Nabi Musa bahwa Rasulullah bersabda, "orang beriman terhadap orang beriman yang lain, tak ubahnya seperti bangunan yang saling menguatkan",22

Diriwayatkan dari an-Nu'mah bin Basyir bahwa Rasulullah bersabda' "perumpamaan orang-orang beriman pada kecintaan, keramahan, dan kelembutan adalah seperti satu sosok

\footnotetext{
${ }^{21}$ Muhammad Syakir Sula, Asuransi Syariah (life ang general) Konsep dan system Operasional, hal :730

22 Abu al-Husein Muslim an-Naisaburi. AlJami' Ash-Shahih. Kittabul Birru wash shallih. Bairut. 1334 H. Hadist no. 80, halm. 417 dalam buku Muhammad Syakir Sula, Asuransi Syariah (life ang general) Konsep dan system Operasional, hal :735
} 
tubuh, bila salah satu anggota tubuh sakit, maka seluruh tubuh akan merasakan sakit. (HR muslim).

Prinsip keempat yang menjadi landasan etika dalam muamalah secara islami adalah ta'awun. Tidak dapat disangkal dengan dahlil-dahlil yang kuat seperti dijelaskan diatas, maka ta'awun merupakan salah satu prinsip utama dalam interaksi muamalah. Bahkan, ta'awun dapat menjadi fondasi dalam membangu sistem ekonomi yang kokoh, agar pihak yang kuat dapat membantu yang lemah, masyarakat yang kaya memperhatikan yang miskin, dan seterusnya. Ta'awun merupakan inti dari konsep takaful, dimana antara peserta yang satu dengan peserta yang lainnya saling menanggung resiko. Yakni melalui mekanisme dana tabbaru' dengan akad yang benar yaitu Aqd Takaful atau Aqd Tabarru'.

5. Al-Amanah (Terpercaya/Jujur)

Al-Qaradhawi mengatakan bahwa diantara nilai transaksi yang terpenting dalam bisnis adalah alamanah'kejujuran'. Ia merupakan puncak moralitas iman dan karakteristik yang paling menonjol dari orang-orang yang beriman. Bahkan, kejujuran merupakan karakteristik para nabi. Tanpa kejujuran, kehidupan agama tidak akan berdiri tegak dan kehidupan didunia tidak akan berjalan baik.

6. Ridha (Suka Sama Suka)

Firman Allah,"Hai orang-orang yang beriman, janganlah kamu saling memakan harta sesamamu kecuali dengan jalan perniagaanyang berlaku dengan suka sama suka diantara kamu."
Abul A'la al-Maududi dalam kitabnya menjelaskan ayat diatas menurutnya, ayat ini telah menetapkan dua perkara sebagai syarat bagi sah nya perdagangan. Pertama, hendaknya perdagangan itu dilakukan dengan suka sama suka diantara dua belahh pihak, tidak berdiri diatas kerugian pihak lain.Keridhaan dalam muamalah merupakan syarat sahnya akad antara kedua belah pihak, sedangkan mengetahui adalah syarat sah ridha. Faktor mengetahui menjadi syarat sah nya ridha, agar dalam transaksi tersebut tidak terjadi gharar. $^{23}$

\section{Riswah (Sogok/Suap)}

Riswan "sogok/suap" merupakan prinsip muamalah yang sangat berat implementasinya. Hal ini disebabkan karena riswan sudah menjadi kultur dalam masyarakat korup seperti Indonesia. Oleh karena itu menghindari Riswan merupakan pekerjaan jihad di bidang ekonomi yang luar biasa berat. ${ }^{24}$ Riswan haram hukumnya dalam islam, karena perbuatan ini dapat merusak tatanan profesionalisme dalam bisnis. Hak seseorang dalam bisnis dapat hilang karena adanya riswanyang dilakukan oleh pihak lain. "Rasulullah melaknan orang yang memberi riswan" (HR. Abu Daud dan Tirmidzi)

8. Maslahah (Kemaslahatan)

9. Khitmah (Pelayanan)

Rasulullah bersabda,"seorang iman (pemimpin) adalah pemelihara dan mengatur urusan (rakyat). Ia akan

\footnotetext{
${ }^{23}$ Muhammad Syakir Sula, Asuransi Syariah (life ang general) Konsep dan system Operasional, hal: 742

${ }^{24}$ Ibid, hal: 742
} 
diminta pertanggungjawaban atas urusan rakyatnya." ( HR. Bukhari dan Muslim) "dan berendah dirilah kamu terhadap orang-orang yang beriman." (QS. AlHijr: 88)

"dan janganlah kamu memalingkan mukamu dari manusia (karena sombong) dan janganlah kamu berjalan di muka bumi dengan angkuh. Sesungguhnya Allah tidak menyukai orang-orang yang sombong lagi membanggakan diri. Dan sederhanalah kamu dalam berjalan dan lunakkanlah suaramu. Sesungguhnya seburuk-buruk suara ialah suara keledai. (QS. Lukman: 18-19).

Orang yang beriman diperintahkan untuk bermurah hati, sopan, peduli untuk melayani orang lain, dan bersahabat saat melakukan dealing dengan mitra bisnisnya. Rasulullah telah mengkatagorikan bahwa orang yang beriman adalah orang yang senantiasa bersahabat dengan orang lain dan orang lain pun dengan mudah bersahabat dengannya. Orang yang tidak memiliki kualitas seperti ini, akan dijauhkan dari nilai-nilai utama. Dala salah satu hadist, Rasulullah bersabda, "semoga Allah memberikan rahmat-Nya kepada orang yang murah hati/sopan pada saat ia menjual, membeli, atau saat ia menuntut haknya."

\section{Tathfif (Kecurangan)}

Tathfif dalam bahasa arab artinya berdikit-dikit, berhemat-hemat atau pelit. Sedangkan, al-muthaffif adalah orang yang mengurangi bagian orang lain tatkala dia melakukan timbangan/takaran untuk orang lain.Salah satu bentuk penipuan dalam bisnis adalah mengurangi takaran dan timbangan. Al-Qura'an menganggap penting persoalan ini, karena itu kami tempatkan sebagai salah satu prinsip muamalah. $^{25}$

\section{Gharar, Maisir, Dan Riba}

Prinsip yang paling utama dalam muamalah islami khususnya untuk Lembaga Keuangan Syariah (LKS) adalah prinsip Gharar, Maisir dan Riba. Ketiga hal inilah yang secara haqiqi menjadi dasar para ulama mengharamkan semua transaksi perbankan, asuransi, penggadaian, bursa efek, leasing, modal ventura dan sebagainya, yang tidak menggunakan prinsip-prinsip syariah. Karena, dalam operasionalnya pasti terdapat salah satu atau kalau tidak tiga-tiganya yang Gharah, Meisir atau Riba. ${ }^{26}$

\section{Metodologi Penelitian}

Metode Pengumpulan data yang digunakan dalam penelitian ini adalah Studi literatur, yaitu dengan cara membaca atau mengambil informasi dari jurnal ilmiah, buku dan juga memanfaatkan internet sebagai sumber informasi. Studi literatur dilakukan untuk mempelajari teori-teori yang berkaitan dengan penelitian, sehingga data yang akan dikumpulkan untuk dianalisis lebih akurat. Teori-teori yang berhubungan dengan penelitian ini antara

\footnotetext{
${ }^{25}$ Muhammad Syakir Sula, Asuransi Syariah (life ang general) Konsep dan system Operasional, hal : 748

${ }^{26}$ Muhammad Syakir Sula, Asuransi Syariah (life ang general) Konsep dan system Operasional, hal : 750
} 
lain tentang asuransisyariahdanasuransi nonsyariah.

\section{Kesimpulan}

Dari pembahasan di atas, maka penulis dapat menarik kesimpulan bahwapada dasarnya asuransi dapat memberikan manfaat bagi pihak tertanggung, antara lain dapat memberikan rasa aman dan perlindungan, sebagai pendistribusian biaya dan manfaat yang lebih adil, polis asuransi dapat dijadikan jaminan untuk memperoleh kredit, sebagai tabungan dan sumber pendapatan, sebagai alat penyebaran risiko, serta dapat membantu meningkatkan kegiatan usaha.

Seiring perkembangan program syariah di berbagai lembaga keuangan, dalam usaha perasuransian pun juga terdapat asuransi syariah. Asuransi syariah merupakan sebuah sistem dimana para partisipan/anggota/peserta

mendonasikan/menghibahkan sebagian atau seluruh kontribusi yang akan digunakan untuk membayar klaim, jika terjadi musibah yang dialami oleh sebagian partisipan/anggota/peserta. Peranan perusahaan disini hanya sebatas pengelolaan operasional perusahaan asuransi serta investasi dari dana-dana/kontribusi yang diterima/dilimpahkan kepada perusahaan.

\section{DaftarPustaka}

Abu Al-Husein Muslim An-Naisaburi. AlJami' Ash-Shahih. Kittabul Birru Wash Shallih. Bairut. 1334 H. Hadist No. 80, Hal. 417 Dalam Buku Muhammad Syakir Sula, Asuransi Syariah (Life Ang General) Konsep Dan System Operasional,
AM. Hasan Ali, Asuransi Dalam Perspektif Hukum Islam, (Jakarta; Prenada Media, 2004),

Fatwa Dewan Syariah Nasional No. 21/DSN-MUI/X/2001 Tentang Pedoman Umum Asuransi Syariah

Heri Sudarsono, Bank Dan Lembaga Keuangan Syariah Deskripsi Dan Ilustrasi, Cet 1, (Yogyakarta: Ekonisia 2003).

Heri Sudarsono, Bank Dan Lembaga Keuangan Syariah Deskripsi Dan Ilustrasi, Cet 2, (Yogyakarta: Ekonisia, 2004).

Hermawan Kartajaya Dan Muhammad Syakir Sula, Syariah Marketing (Bandung: Mizan Pustaka, 2006)

M. Solahudin, Lembaga Ekonomi Dan Keuangan Islam, (Surakarta : Muhammadiyah University Press, 2006).

Muhaimin Iqbal, Asuransi Umum Syariah Dalam Praktik (Upaya Menghilangkan Gharar, Maisir, Riba), (Jakarta: Gema Insani Press, 2005).

Muhamad Abdul Manan, Teori Dan Praktek Ekonomi Islam, (Yogyakarta: Dana Bhakti Wakaf)

Muhammad Syakir Sula, ASURANSI SYARIAH (Life And General), (Jakarta: Gema Insani Press,2004).

Nurul Huda Dan Mohamad Heykal, Lembaga Keuangan Islam: Tinjauan Teoritis Dan Praktis, (Jakarta: Prenada Media Group, 2010). 